\title{
If We Could Choose The Way We Pay: The Impact Of Decision Complexity On Tax Scheme Preference
}

\author{
Jeffrey P. Katz, (Email: jkatz@ksu.edu), Kansas State University
}

Richard L. Ott, Kansas State University

\begin{abstract}
A continuing debate exists about how the complex U.S. tax code has resulted in counter-productive business decisions. Our study examines how tax policy impacts taxpayer decision-making. We present a model addressing factors impacting taxpayer decision-making and test our resulting hypotheses using an experimental design drawn from industrial and organizational psychology. We find that the context of the taxpayer's personal situation significantly affects the decision to favor changes in tax policy. Consistent with our hypotheses, we find that taxpayers having a more complex tax situation will tend to support a tax simplification proposal less than those with simpler tax situations. Our study provides unique evidence that taxpayers having more complex tax situations feel more in control of their decisions under the existing tax structure than those having simpler tax situations. Implications for decision-making researchers and tax policymakers are offered.
\end{abstract}

\section{INTRODUCTION}

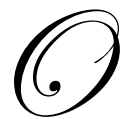

ver the past 10 years there has emerged an aggressive debate about the impact that national tax policy has on the decision-making of the typical taxpayer. Critics of existing U.S. tax policy argue that the tax regulations are too lengthy (Forstmann \& Moore, 1998). The popular press has followed the debate with great interest since tax reform measures took place in 1997 (Harbrecht \& McNamee, 1998). Professionals in the field have asserted that the current tax system, "...has become a maze of unfairness, complexity and inefficiency. As a result, there has been increased debate regarding replacing our current federal income tax" (Miller, 1998: 9). More recently, on January 7, 2005 President Bush signed Executive Order 13369 creating the President's Advisory Panel on Federal Tax Reform. The panel is charged with developing a report identifying tax policy options that include simplifying Federal tax laws. The current debate centers on the issue of how taxpayers will perceive the fairness of changes in the tax regulations thus impacting their willingness to support such changes (Donlan, 2004).

Our objective is to examine how typical taxpayers assess external and internal factors affecting their decision to choose among possible taxation systems. Prior research has shown that self-interest, perceived equity, tax knowledge, and certain demographic characteristics impact taxpayer attitudes toward tax systems (McGowan, 2000) and that taxpayer reporting of income levels will vary based on the tax scheme (Hite \& McGill, 1992). We bridge these issues by developing a decision-making model and testing its explanatory capability using an experimental design.

We believe this is an important area of research that links the fields of tax accounting and individual decision-making. It is certainly an important public policy area since it has been estimated that approximately $\$ 100$ billion is underreported each year by U.S. taxpayers who believe the existing taxation system is unfair. Previous researchers have encouraged the application of experimental methodologies to move beyond classical expected utility theory into theories of behavior (Alm, 1991). Economists have investigated the aggregate impact of tax policy changes (see for example, Cassou \& Lansing, 2004) but little research has been conducted that seeks to examine tax policy choices at the individual level. We attempt to do so. 
Our research is a direct response to Congleton's (2002) call for examination of the balance between taxpayer behavior and the factors that lead to decisions potentially impacting the activities of tax collecting agencies. According to previous research, the best way to ensure that a structural change to the tax system is effective is to assess how taxpayers make their decisions to participate in the system (Alm, Bahl \& Murray, 1990; Alm, Jackson \& KcKee, 1992). Alm (1996) suggests that the central issues in public economics are the design and acceptance of a tax system.

The current study extends our understanding of taxpayer support for changes in national tax collection policies by experimentally assessing the roles that taxpayer self-interest and personal tax situation (measured by level of taxpayer tax-filing complexity) have on support of a tax scheme. Flat tax proposals were chosen as the base example for this study because they have been the focus of attention for several years and provide a consistent structural framework for analysis. There are certainly variations in flat tax proposals. However, we believe the results of this study would not be affected by changing the flat tax proposal because complexity of tax filer status and taxpayer self-interest, variables of interest in this study, can be examined regardless of the tax scheme under evaluation.

The broad research questions addressed through our work are:

1. Is there a relationship between taxpayer support of a flat tax proposal and the complexity of the taxpayer's tax situation?

2. Is there a relationship between taxpayer support of a flat tax proposal and taxpayer self-interest?

We believe answers to these questions will provide policymakers and researchers with needed information regarding potential tax simplification proposals. That is, taxpayers may complain about the complexity of the existing tax regulations but only want to simplify regulations if it is of personal benefit to do so.

Our paper is divided into five sections presenting the theoretic framework, defining the exogenouslydeveloped flat tax scheme, describing the methodology, reporting the results, and offering discussion and implications of our work.

\section{THEORY \& FRAMEWORK}

It has been argued that personal financial self-interest is a primary motivation for many business decisions (Jensen \& Meckling, 1976). In fact, in studies assessing the competing effects of financial self-interest and role of external monitoring, it was found that personal self-interest was a dominant factor in determining business choices (Tosi, Katz \& Gomex-Mejia, 1997). In the case of individual decisions to comply with an externally imposed tax scheme, the financial impact of the individual will most likely overwhelm the potential for monitoring by an external party such as the Internal Revenue Service (Alm et al., 1992; Congelton, 2002). This suggests the context of the decision, that is, level of self-interest, may be an important factor in assessing taxpayer support for changes in the national tax collection process.

Figure 1 contains a decision-making model adapted from Roberts (1998) for use in this study. Unlike previous decision-making models, Figure 1 includes endogenous and exogenous factors of relevance to decisions impacting taxpayer decision. The model also includes the cognitive processing activities of the decision-maker.

In developing a model to better understand taxpayer decision-making we draw from the existing external environment to represent exogenous factors by considering the existing complex tax scheme (see for example, Forstmann et al., 1998) and the proposals for a national flat tax scheme (Armey, 1995). Therefore, we suggest the primary exogenous factor impacting cognitive reasoning for a taxpayer's decision-making process is the perceived complexity of the current tax laws and perceived simplicity of the flat tax proposal.

We model two levels of tax complexity as inputs into the taxpayer's cognitive processing by linking the cognitive process to the output: The individual tax return. That is, complexity is operationalized through the use of tax 
returns. Thus, the more complex the tax regulations, the more complex the tax return is in complying with the regulations. Tax complexity can also be seen in the cognitive processing section of the model as part of the relevant facts that aid the taxpayer in analyzing and synthesizing relevant information needed for decision-making (Alm et al., 1990).

Figure 1: Model Of Factors Impacting Taxpayer Decision-Making

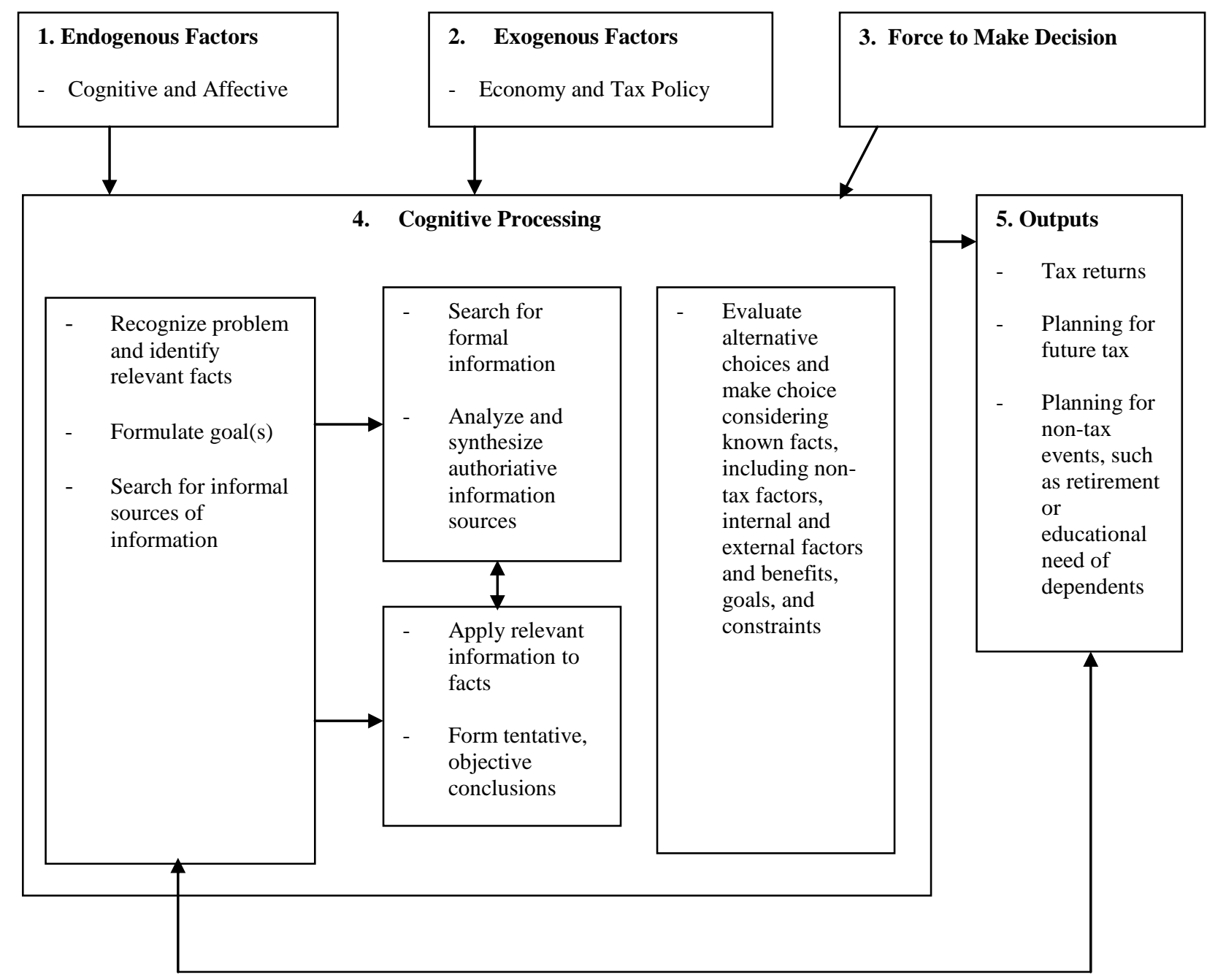

In the context of the decision-making model, we believe taxpayers with simple tax situations (for example, few itemized deductions) will support the flat tax proposal more than taxpayers with complex tax situations. On the other hand, taxpayers with complex tax situations may be expected to favor a simpler tax scheme more because of the expense in tax preparation and planning under the current system. However, because taxpayers in complex situations have the resources to conduct tax planning and reduce their tax liabilities, they may perceive control over their tax destiny. Thus, we believe taxpayers may not favor a simpler tax system if they can potentially minimize their tax liabilities under the current system. Of course, given the agency argument of self-interest, the critical issue would be whether taxpayers perceive a financial gain under the flat tax scheme compared to the current system. Conversely, 
taxpayers with simple tax returns may believe their taxes are beyond their control because tax-planning opportunities are limited when one does not have to itemize income-reducing expenses. Thus, taxpayers in simple tax situations may believe they can do very little to affect their tax liabilities. Therefore, tax situation complexity may be less of an issue to taxpayers filing simple tax returns.

With these cognitive processes in mind, we propose the following hypothesis:

H1: Taxpayers having simple tax situations will more strongly support the flat tax proposal than those having more complex tax situations.

A second factor of interest is the taxpayer's self-interest for paying less tax under the flat tax proposal than under the current scheme. In other words, given the self-interest of taxpayers, we propose support of the flat tax proposal will occur if it reduces taxpayers' personal taxes. That is, self-interest can be viewed as part of the individual cognitive factors that impacts the taxpayer's cognitive processing and is recognized as part of the relevant facts used in coming to a decision on the level of support for a flat tax proposal. Therefore we propose the following hypothesis:

H2: Taxpayers paying less tax under the flat tax proposal will more strongly support it than those paying more tax.

\section{FLAT TAX SCHEMES}

It has been estimated the Internal Revenue Service publishes over 480 tax information submission forms along with 280 companion forms explaining how to correctly complete the forms. As a result, Americans devote 5.4 billion hours filling-out and submitting forms to comply with Internal Revenue Service regulations. The annual cost of complying with the regulations has been estimated to be $\$ 200$ billion (Armey, 1995). These large social costs resulting from tax regulation complexity have led to an outcry for tax simplification and alternative means of taxation. Value-added taxes (VAT), general sales taxes, and flat taxes based on levels of earned income are examples of alternatives being debated by policy makers and academic researchers (Alm, 1996; McGowan, 2000; Miller, 1998).

Most flat tax proposals seek to "simplify or eliminate" the existing regulations. Under the flat tax proposal, individuals only pay taxes on wages, salaries, and pension income. There are no deductions or credits allowed for certain expenses. A flat tax rate of 17 percent is applied to taxable income regardless of the income level (Armey, 1995).

The pros and cons of flat tax schemes are a matter of policy and academic debate beyond the scope of this study. However, relevant research has been conducted to determine the effects of a flat tax on the economy, charities, and housing (See for example, Norr 1999; Barry 1996; Seldon \& Boyd 1996). In an early defense of the existing tax scheme, Hicko (1996) insists a national flat tax will not work effectively as a tax collection strategy. However more recently, Iyer and Seetharaman (2000) and Tideman, Akobundu, Johns and Wutthicharoen (2002) conclude that a flat tax system increases horizontal equity relative to the current system. There is a long history of tax research suggesting the existing national tax collection process is disparate to groups of taxpayers (see for example, Seetharaman, 1994 and Young, Nutter \& Wilkie, 1999).

Public opinion polls have also been taken to determine taxpayer support for a flat tax proposal. The National Center for Policy Analysis reported the results of a poll taken by Fabrizio and McLaughlin (1998) after the 1998 national elections. They report that 63 percent of those surveyed favored a 17 percent flat tax while only 19.5 percent of respondents opposed it. A separate survey conducted in 1999 by the NCPA indicates mortgage interest, health insurance, and state and local taxes would not be deductible items under a flat tax plan. Fifty-one percent of the respondents indicated support for a flat tax program while 37 percent indicated opposition. It has been suggested that the difference in how respondents view tax issues may be attributable to the context in which the data is gathered and, therefore, in differences in perceptions regarding how the flat tax will affect respondents (Wartick, Mateo \& Vines, 1999). 


\section{METHOD}

To test our hypotheses regarding the factors impacting taxpayer decisions to support and voluntarily adopt differing tax schemes, we developed an experimental simulation that controlled for the exogenous and output factors in the cognitive processing model described in Figure 1. We did so by designing a full-crossed 2 by 2 factorial experiment and administered the experimental protocol in a controlled setting. We examined decision-making under high and low levels of potential decision-maker self interest and under tax conditions that would be perceived as simple or complex. The experimental design used has been commonly employed in cognitive testing for assessing the direct and interactive effects of variables on decision-maker behavior (Staw, 1976).

Two levels of tax complexity (exogenous conditions) were employed. Simple and complex tax returns (output conditions) were designed as scenarios for the subjects as context variables. In the low condition, the simple tax return had no deductions or only itemized deductions. In the high condition, the complex tax return contained income from rental property, passive activities, capital gains/losses and tax credits as well as itemized deductions.

Two levels of self-interest (endogenous factors) were designed. In the high level, subjects were to pay less tax under the flat tax proposal, while in the low condition subjects were to pay more under the flat tax proposal than under the current system.

There are other constructs suggested to have an impact on an individual's choice among alternatives in a tax policy context, specifically, distributive justice and fairness (Porano 1984; Milliron et al. 1989; and Hite \& Roberts 1992). Although our research design does not control for these issues, subjects' responses to a post experimental questionnaire suggest that these factors were not of major importance to the subjects in their decision-making.

\section{Procedures}

Subjects were provided written highlights of a flat tax scheme. The subjects were then asked to assume the identity of the tax filer and review the tax return prepared using the current system of taxation. Subjects were given time to carefully examine the tax return provided as part of the experimental protocol. The subjects were then asked to study a worksheet that presented the tax liabilities calculated using the same data for the current and flat tax systems. Subjects were instructed to review this information then indicate their level of support for the flat tax scheme. A Likert-type scale of 1 (strongly oppose) to 7 (strongly support) was used to measure the level of support. Subjects answered validity and demographic questions following the experiment. The tax returns and instruments were pre-tested twice and modifications were made based on the results of the pre-tests.

\section{Subjects}

Subjects were college students at a major Midwestern state university, the majority were students in accounting classes. In this study, subjects were presented with information concerning a specific flat tax proposal and the tax liabilities calculated under the proposed flat tax system and the current system. They were also given a completed tax return for evaluation. Subjects were asked to make a judgment based on the information provided. Subjects were compensated for their participation by being provided with extra course credit for their participation in the study. A total of 192 completed responses were received.

\section{Post-Experimental Manipulation Assessment}

There were six post-experimental questions designed to measure the validity of the experimental manipulations (see Appendix). Subjects were asked: 1) if they compared the two tax liabilities, 2) whether they would pay more or less tax under the flat tax system, 3) whether they considered the savings on tax preparation fees if the flat tax proposal was adopted, 4) whether they considered the tax return prepared under the current system as simple or complex, 5) to weight the complexity of the tax return under the current system, the comparison of the tax liabilities under both systems, and other factors in making their decisions, and 6) if they considered anything else other than the complexity of their tax returns and the amount of taxes owed under the flat tax proposal. 
There were no significant differences among the four experimental groups. Subjects in all groups compared the tax liabilities under both tax systems ( 95 percent of the subjects did so), determined whether they would pay more or less tax under the flat tax system, and weighted the factors similarly in their decision. Fifty-eight percent of the subjects considered the money they would save in tax preparation fees (if the flat tax proposal became law) in making their decision to support or oppose the flat tax proposal. There were no significant differences among groups in consideration of this factor. We should note that the scenarios of the experiment were not affected by taking the savings in tax preparation fees into account. For example, if the tax liability under the flat tax system was greater than the liability under the current system, this condition would hold even if the tax preparation fees were considered and the savings subtracted from the difference in tax liabilities. The statement concerning tax preparation fees was merely used to make the scenarios more realistic.

In summary, four groups of subjects participated in this study. One group of subjects received a simple tax return and a worksheet that indicated a lower tax liability calculated using the flat tax proposal $(n=63)$. Another group was given the simple tax return and the worksheet that indicated a lower tax liability under the current system $(\mathrm{n}=38)$. The other two groups were given complex returns. One group was given a worksheet that indicated a lower tax liability under the flat tax scheme $(n=45)$, the other a lower tax liability under the current system $(n=46)$. Subjects answered validity questions to insure they compared the tax liabilities and knew which system benefited them.

\section{RESULTS}

\section{Demographics}

Twenty-eight percent of the subjects were accounting majors, seven percent finance majors, 12 percent management majors, 12 percent marketing majors, eight percent a combination of the above, and 33 percent nonbusiness majors. An analysis of variance indicated no significant differences in support of the flat tax proposal based on college major. Forty-six percent of the subjects had previously prepared their own tax returns, 23 percent had prepared someone else's tax return, and seven percent had prepared a business tax return indicating a high level of knowledge about the taxation process. Analysis of variance between groups indicated no significant differences in support of the flat tax proposal between those subjects who had had one or more tax courses and those who had not taken a tax course.

\section{Analysis}

Table 1 presents the analysis of variance results with complexity and self-interest as the independent variables and level of support for the flat tax proposal as the dependent variable. Both independent variables of interest are significant $(\mathrm{p}<.05)$ while the interaction of these two variables is not. The results indicate support for both hypotheses.

Table 2 presents the univariate results for each of the four groups on support of the flat tax proposal and the results of the Duncan Multiple Comparison Test. The means are calculated on the dependent variable $(1=$ strong opposition to and $7=$ strong support). Group 1 (simple tax return and self-interest in favor of flat tax) had a mean of 5.3 indicating support of the flat tax proposal. Group 3 (complex tax return and self-interest in favor of flat tax) had a mean of 4.5 indicating limited support of the flat tax proposal. Group 2 (simple tax return and self-interest in favor of current system) is neutral on the flat tax proposal (mean $=4.0$ ). Group 4 (complex return and self-interest in favor of current system) did not support the flat tax proposal (mean $=3.6)$. The means of all groups were in the expected directions. 
Table 1: Analysis of Variance Dependent Variable-Tax Payment Choice Independent Variables-Tax Complexity \& Self-Interest (n=192)

\begin{tabular}{|l|c|c|c|c|c|}
\hline Source of Variation & Sum of Squares & DF & Mean Square & F & Sig of F \\
\hline Main Effects & 74.040 & 2 & 37.020 & 14.208 & .000 \\
\hline Tax Complexity & 16.205 & 1 & 16.205 & 6.219 & .013 \\
\hline Self-Interest & 48.729 & 1 & 48.729 & 18.702 & .000 \\
\hline 2-Way Interactions & & & & & \\
\hline Tax Complexity/Self-Interest & 1.315 & 1 & 1.315 & .505 & .478 \\
Explained & 77.724 & 3 & 25.908 & 9.943 & .000 \\
\hline Residual & 489.854 & 188 & 2.606 & & \\
\hline Total & 567.578 & 191 & 2.972 & & \\
\hline
\end{tabular}

Table 2: Means of Experimental Groups Duncan Multiple Comparisons Test Dependent Variable-Decision Choice (1=Strongly Oppose, 7=Strongly Support)

\begin{tabular}{|l|c|c|}
\hline & Benefit--Flat Tax System & Benefit--Current System \\
\hline & $\mathbf{1}$ & 2 \\
\hline 1 Simple Tax Return & Group 1 - Mean=5.3 & Group 2 - Mean=4.0 \\
\hline 2 Complex Tax Return & Group 3 - Mean=4.5 & Mean=3.6 \\
\hline $\begin{array}{l}\text { Duncan Multiple Comparisons Tests indicated Group 1 was significantly different from Groups 2, 3, and 4. Group 3 was also } \\
\text { significantly different from Group 4. }\end{array}$ \\
\hline
\end{tabular}

Means for the simple tax return groups are higher than the means in the two complex tax return groups under both levels of self-interest. The means for the complex and simple return groups are higher (indicating more support for the proposal) than the means of the groups benefiting from the current system. Duncan Multiple Comparison Test results indicate a significant difference between Group 1 and the other three groups. In addition, the Scheffe' Multiple Comparison Test indicated Group 1 is significantly different from Groups 2 and 4.

Table 3 presents the bivariate correlations between support for the proposal and tax complexity and selfinterest. Both correlations are statistically significant $(p<.01)$. Both variables are negatively correlated to support of the tax proposal. As tax complexity increases (simple $=1$ and complex $=2$ ), support for the tax proposal decreases. Therefore, as the self-interest variable is decreased, (indicating a tax liability less under the flat tax system) support for the flat tax proposal increases.

\section{DISCUSSION}

The results of our analysis provide empirical support for both hypotheses. We found support for a flat tax scheme is affected by exogenous factors, as measured by the level of tax complexity, and endogenous factors, as measured by level of self-interest. The results suggest that the more complex the tax scheme, the less likely the taxpayer will support changes toward a flat tax proposal that reduces the opportunities for self-interest and reduces the likely cost of external monitoring. We believe this occurred because taxpayers with complex tax situations tend to perceive more control over their tax liabilities through their tax planning efforts. These taxpayers support a simpler tax system only if it benefits them (that is, reduces their tax liabilities).

Table 3: Correlation Support and Tax Complexity/Self Interest

\begin{tabular}{|c|c|c|}
\hline \multirow{4}{*}{ Support } & Tax Complexity & Self Interest \\
\hline \multirow{3}{*}{} & -.2198 & -.3217 \\
\cline { 2 - 3 } & $(\mathrm{n}=192)$ & $(\mathrm{n}=192)$ \\
\cline { 2 - 3 } & $\mathrm{p}=.002$ & $\mathrm{p}=.000$ \\
\hline
\end{tabular}


Further, we believe taxpayers with simple tax situations tend to have less control over their tax liabilities because, with limited choices for income deductions, the opportunities for tax planning are reduced considerably. Thus, it appears that taxpayers in such a situation consider their tax liabilities to be out of their control. Their support of any new tax proposal is also limited to whether the proposal benefits them. Our conclusions seem to be supported by related research (Congleton, 2000; Iyer \& Seetharaman, 2000).

Based on our study, the dominant factor in determining support for a new tax scheme appears to be taxpayer self-interest consistent with the agency literature on incentive alignment and monitoring (Jensen \& Meckling, 1976; Tosi et al., 1997). That is, individual taxpayer support for a new tax scheme will be contingent at the first order on whether the taxpayer personally benefits through perception of control or financial outcome. Secondarily, our study shows that the taxpayer will also evaluate the likely level of monitoring by external parties under the new tax scheme (see Table 3). Our study suggests this is true for taxpayers with simple or complex tax situations.

There is recent evidence to support this contention. Dalrymple (2003), reporting on a study conducted by the U.S. Department of Treasury's Inspector General, indicates that a group of taxpayers having complex tax situations chronically take advantage of provisions of the exciting tax regulations by filing late returns and paying their taxes late. The taxpayers in this group earned more than twice the average taxpayer and most used professionals to help prepare their taxes. Interestingly, more that 17 percent in this taxpayer category that includes individuals having relatively complex tax situations, analogous to our experimental group having high tax complexity and favoring the non-flat tax scheme, had paid no taxes by the imposed April $15^{\text {th }}$ deadline. This provides limited anecdotal evidence that decision-makers will take exogenous factors into consideration when determining the most effective way to derive personal benefits. In the case of the U.S. Department of Treasury study, the authors conclude that the cumulative effect of taxpayers using the tax regulations to their benefit could, "...erode public confidence in the fairness of the tax system...the (tax return) extension is the strategy of choice for those unable or unwilling to pay by April 15 ${ }^{\text {th }}$ (Dalrymple, 2003: C2.).

\section{Policy Implications}

Most people would agree the current system of taxation is too complex. There are many reasons for the complexity of the existing regulations. We believe there are many planning opportunities, viewed as part of the cognitive processing part of the model contained in Figure1, available to taxpayers under the current tax scheme. So, what do the results of this study suggest to policymakers? We offer three.

First, policymakers can take solace in the fact that although taxpayers complain about the complexity of the current system of taxation the results of our study suggest that as long as it is beneficial to them, compared to a simpler tax scheme, they would prefer the existing system. Thus, it is conjecture at this point as to whether there are more winners and fewer losers under the flat tax scheme compared to the current system.

Second, more independent research needs to be conducted to determine the economic and social effects of any new tax proposal. For example, more research should be conducted on the effects of eliminating itemized deductions and tax credits. The elimination of these tax benefits may have long run and short run effects on the economy and society in general.

Finally, tax simplification and flat tax schemes should not be confused. One may exist without the other. It just so happens that the Armey proposal contains both. If it is determined that some form of tax simplification (with or without a flat tax) will benefit society and the economy in the long run, policymakers will need to develop a strategy to promote it to the general public. It is incumbent upon any strategy to include information about the winners and the losers under the new system and how it will benefit society in the long run. In our opinion, for taxpayers to support a considerable change in tax policy, there must be more winners than losers. Thus, the taxpayer perception and cognitive choice of tax schemes is an important issue. 


\section{Limitations}

There is a tradeoff between external and internal validity whenever the research method of choice is a laboratory experiment. We recognize this limitation. Internal validity is strong because the design was structured to test subjects' support for, or opposition to, a flat tax proposal under controlled conditions for examining tax complexity and self-interest. Post experiment questions validated that subjects did, in fact, compare the tax liabilities of the two tax systems. Relevant demographic variables were also tested to validate that no significant differences existed among these variables. However, we feel that since the judgment to support or oppose the flat tax proposal required no technical expertise in tax law, and no prior knowledge of the Armey flat tax proposal, external validity concerns are reduced. We believe it is likely that the results would be consistent if the experiment was conducted among the general population since taxpayers could be expected to act in their own interest.

In addition, this study examined just one of the stakeholders in any change in tax law. Certainly, corporations may have a different perspective. However, we would also expect a corporation's board of directors to act in the interest of its shareholders. This is clearly an area of future research for those interested in corporate behavior and corporate taxation.

\section{CONCLUSIONS}

Public policymakers always wonder about the unintended consequences of changes to policies. The objective of this study was to develop and test a model of individual decision-making that separated the external factors from decisions at the individual level. We found that self-interest had a more dominant effect than potential monitoring, based on the level of tax situation complexity. The results suggest that potential policy changes impacting individuals should be "pre-tested" using a cognitive processing and decision model as we have demonstrated.

Existing taxpayers may be concerned about the complexity of the current tax regulations. However, the results of our study suggest that taxpayers with complex tax situations will be less supportive of a simplified system than taxpayers with simple tax situations. This is true when both benefit from the change to a simplified tax system. We believe the reason for this is the ability to have more control over their tax liabilities under the current system than those taxpayers with simple returns. Control of their tax liabilities is restricted considerably under the flat tax scheme. Therefore, subjects may have perceived they could take advantage of more "loopholes" in the tax law under the current system than in a system that eliminates deductions and credits.

However, it should be noted that when the change in tax systems does not benefit them there is no significant difference in the support of the flat tax proposal between the two groups of taxpayers. Taxpayers with the simple tax conditions are neutral with respect to support and those with complex situation slightly oppose the change. Therefore, tax complexity is not as important as self-interest in explaining the support of or opposition to a simplified tax system.

In our opinion, policymakers have two issues to consider. First, they may continue making rules that make the tax scheme more complex to achieve non-revenue objectives or they can simplify the system. If they choose the former, they should make an effort to explain why the tax law is so complex thereby providing reasonable rationale for the existing structure.

Second, simplifying the tax system has been attempted in the past with very little success. In fact, some would argue that tax law has become more complex as Congress has attempted to simplify it. Therefore, attempts to simplify the tax structure should be considered from macro-economic, as well as at the individual taxpayer level, to assess potential impacts. Clearly, more independent research is needed to determine the short run and long run effects on the economy and society in general.

\section{REFERENCES}

1. Alm, J. 1991. A perspective on the experimental analysis of taxpayer reporting. Accounting Review. 66(3): 577593.

2. Alm, J. 1996. What is an "optimal” tax system? National Tax Journal. 49(1): 117-133. 
3. Alm, J., R. Bahl, \& M. Murray. 1990. Tax structure and tax compliance. Review of Economics and Statistics. 72(4): 603-613.

4. Alm, J., B. Jackson \& M. McKee. 1992. Estimating the determinants of taxpayer compliance with experimental data. National Tax Journal. 45(1): 107-114.

5. Armey, D. 1995. The Freedom Revolution, Washington DC: Regnery Publishing.

6. Barry, J. 1996. How a flat tax would affect charitable contributions. Backgrounder No. 1093, (December 16) Heritage Foundation.

7. Cassou, S. and K. Lansing. 2004. Growth effects of shifting from a graduated-rate tax scheme to a flat tax. Economic Inquiry. 42(2): 194-213.

8. Congleton, R. 2002. Risk-averse taxpayers and the allocation of tax enforcement efforts: Law enforcement or leviathan? Some empirical evidence. Public Finance Review. 30(5): 456-476.

9. Dalrymple, M. 2003. Fewer taxpayers filing by April $15^{\text {th }}$, government finds. Kansas City Star, August 13: C2.

10. Donlan, T. 2004. Fair or Simple? Barron's. 84(15): 35.

11. Dunbar, A. 1996. The impact of personal credits on the progressivity of the individual income tax. Journal of the American Taxation Association 18(1): 1-30.

12. Forstmann, T. \& S. Moore. 1998. Abolish the tax code not the IRS. Chief Executive. 134: 44-50.

13. Harbrecht, D. \& M. McNamee. 1997. Now that we've made taxes more complex, let's simplify them. Business Week. 35(42): 45.

14. Hicko, S.E. 1996. The flat tax: Why it won't work for America. Addicus Books.

15. Hite, P. \& G. McGill. 1992. An examination of taxpayer preference for aggressive advice. National Tax Journal. 45(4): 389-403.

16. Hite, P. \& M. Roberts. 1992. An analysis of tax reform based on taxpayers' perceptions of fairness and selfinterest. Advances in Taxation 4:115-137 1992.

17. Iyer, G. \& Seetharaman, A. 2000. An evaluation of alternative procedures for measuring horizontal inequity. Journal of the American Taxation Association. 22(1): 89-110.

18. Jensen, M. \& W. Meckling. 1976. Theory of the firm: Managerial behavior, agency costs and ownership structure. Journal of Financial Economics 3: 305-360.

19. McGowan, J. 2000. The effects of political affiliation on taxpayers' attitudes toward alternative tax systems. Journal of the American Taxation Association. 22(1): 111-128.

20. Miller, J. 1998. The implications of federal tax reform. Pennsylvania CPA Journal 69(3): 9-13.

21. Milliron, V., P. Watkins \& S. Karlinsky. 1989. Policy judgments of taxpayers: An analysis of criteria employed. Advances in Taxation. 2:201-221.

22. National Center for Policy Analysis. 1999. A flat tax income tax. http://www.ncpa.org/w/w76.html.

23. Porcano, T. 1984. Distributive justice and tax policy. The Accounting Review, 59: 619-636.

24. Roberts, M. 1998. Tax accountants' judgment/decision-making research: A review and synthesis. Journal of the American Taxation Association, Spring, 78-121.

25. Seetharaman, A. 1994. An isolation of the effects of personal deductions, tax credits and the tax rate schedule on income tax progressivity and income inequality. Journal of the American Taxation Association, 6(1): 101-121.

26. Seldon, B. \& R. Boyd. 1996. Economic effects of a flat tax. National Center for Policy Analysis Report No. 205, June.

27. Staw, B. 1976. Knee-Deep in the big muddy: A study of escalating commitment to a chosen course of action. Organizational Behavior and Human Performance 16: 27-44.

28. Tideman, N., E. Akobundu, A. Johns, and P. Wutthisharoen. 2002. The avoidable excess burden of broad-based U.S. taxes. Public Finance Review. 30(5): 416-441.

29. Tosi, H., J. Katz, \& L. Gomez-Mejia. 1997. Disaggregating the agency contract: The effects of monitoring, incentive alignment, and term in office on agent decision-making. Academy of Management Journal 40 No. 3 : 584-602.

30. Wartick, M., S. Madeo, \& C. Vines. 1999. Reward dominance in tax-reporting experiments: The role of context. Journal of the American Taxation Association, 21(1): 20-31.

31. Young, J., S. Nutter, \& P. Wilkie. 1999. A re-examination of the effects of personal deductions, tax credits and the tax rate schedule on income tax progressivity and income inequality. Journal of the American Taxation Association, 21(1): 32-44. 